\section{Hydrotalcite-supported Pd-Cu catalyst for nitrate adsorption and reduction from water}

\author{
WANG Ying ${ }^{1,2}$, QU Jiuhui ${ }^{1}$, LIU Huijuan ${ }^{1}$ \\ \& WU Rongcheng ${ }^{1}$
}

1. State Key Laboratory of Environmental Aquatic Chemistry, Research Center for Eco-environmental Sciences, Chinese Academy of Sciences, Beijing 100085, China;

2. Graduate School of Chinese Academy of Sciences, Beijing 100039, China

Correspondence should be addressed to Qu Jiuhui (email: jhqu@, rcees.ac.cn)

Received October 13, 2005; accepted December 31, 2005

Abstract Hydrotalcite-supported $\mathrm{Pd}-\mathrm{Cu}$ catalyst for nitrate adsorption and catalytic reduction from water is prepared by co-impregnation method and characterized by surface area (BET), X-ray diffraction (XRD), scanning electron microscope (SEM), transmission electron microscope (TEM) and X-ray photoelectron spectrum (XPS). The performance of adsorption and hydrogenation of nitrate was evaluated and compared with $\mathrm{Al}_{2} \mathrm{O}_{3}, \mathrm{TiO}_{2}$, and HZSM-supported $\mathrm{Pd}-\mathrm{Cu}$ catalysts. The experimental results demonstrated that hydrotalcite-supported $\mathrm{Pd}-\mathrm{Cu}$ catalyst exhibited a high surface area $\left(185.3 \mathrm{~m}^{2} / \mathrm{g}\right)$ and mesopore structure (average pore diameter of 52.2 $\AA$ ). The active metal clusters were homogeneously dispersed on the support, and the size of the most was less than $10 \mathrm{~nm}$. Excellent adsorption for nitrate resulted from that nitrate ions were forced to enter the interlayer space when the calcined hydrotalcite regenerated layer structure in nitrate solution. The adsorption isotherm could be well described by the Langmuir model. The comparison between the adsorption and catalytic hydrogenation for nitrate using hydrogen indicated that nitrate reduction on hydrotalcite-supported $\mathrm{Pd}-\mathrm{Cu}$ catalysts was a consecutive and dynamic adsorption and catalytic hydrogenation process. Compared with the $\mathrm{Al}_{2} \mathrm{O}_{3}, \mathrm{TiO}_{2}$, and $\mathrm{HZSM}$ supported catalysts, hydrotalcite-supported $\mathrm{Pd}-\mathrm{Cu}$ catalyst possessed higher catalytic activity and selectivity. The analysis on the dissolving of metals in the solution demonstrated that there was hydrolyza- tion on the surface of the hydrotalcite-supported $\mathrm{Pd}-\mathrm{Cu}$ catalyst. However, the concentrations of dissolved metals in the solution were lower than the standard executed in China. The activity of the hydrotalcite-supported $\mathrm{Pd}-\mathrm{Cu}$ catalyst for nitrate reduction kept steady after repeated use.

Keywords: hydrotalcite, nitrate, adsorption, catalytic reduction.

With the rapid development of industry and agriculture, the nitrate contamination in groundwater becomes increasingly serious in many countries ${ }^{[1]}$. Therefore, the remediation of nitrate-contaminated groundwater is one of the targets urgently confronted.

At present, available methods for nitrate removal from water include physical-chemical ${ }^{[2]}$, biological ${ }^{[3]}$ and catalytic reduction processes ${ }^{[4]}$. Physical-chemical process only concentrates nitrate ions into brine, which has to be treated afterwards. Biodenitrification can reduce nitrate ions in water. However, possible bacterial contamination, the presence of residual organics, and the possible increase in chlorine demand in purified water are not suitable for the dispersed water supply on a small scale. The catalytic reduction of nitrate using $\mathrm{H}_{2}$ as reducing agent has been widely paid attention to by many researchers due to higher activity and easier control.

The catalytic denitrification was first described in 1989 by Vorlop et al. ${ }^{[5]}$. In this process, nitrate ions were reduced to nitrogen using $\mathrm{H}_{2}$ as reducing agent over bimetallic catalyst $\left(\mathrm{Pd}-\mathrm{Cu} / \mathrm{Al}_{2} \mathrm{O}_{3}\right)$. It has been proved that the catalytic reduction of nitrate is strongly influenced by many factors such as the property of catalyst ${ }^{[6]}$, the water quality ${ }^{[7]}$, the conditions of the reaction ${ }^{[8]}$, and diffusion, ${ }^{[9]}$ in which the catalytic property of catalyst is the most important factor. As reported, bimetallic Pd-Cu, Pd-Sn or Pd-In catalysts show higher activity and selectivity for nitrate reduction ${ }^{[4,10,11]}$. Different supports, such as $\gamma-\mathrm{Al}_{2} \mathrm{O}_{3}{ }^{[12]}$, $\mathrm{SiO}_{2}{ }^{[6]}, \mathrm{TiO}_{2}{ }^{[10]}, \mathrm{ZrO}_{2}{ }^{[13]}, \mathrm{SnO}_{2}{ }^{[14]}$, and activated carbon ${ }^{[11]}$, have an apparent influence on the capacity of the catalyst. Generally, the support having adsorptive capability for pollutant is favorable for improving catalytic property of catalyst. However, for general material for nitrate reduction as mentioned above, the adsorption performance for nitrate is limited. Therefore, selecting a more suitable catalyst support for the catalytic reduction of nitrate is required.

Hydrotalcite-type (HT) compounds, a kind of anionic clays, possess the performance of memory for 


\section{ARTICLES}

layer structure, that is, when calcined hydrotalcite is put in water, they can reconstruct the original layer structure. Accordingly, anions in water may enter the interlayer space to be concentrated, which is beneficial to the catalytic reactions. Therefore, hydrotalcite material has been widely used as catalyst or the support of catalyst in the field of catalysis ${ }^{[15]}$.

In this study, the hydrotalcite-supported $\mathrm{Pd}-\mathrm{Cu}$ catalyst was prepared by coimpregnation method. The performance of adsorption and hydrogenation of nitrate was evaluated and compared with the $\mathrm{Al}_{2} \mathrm{O}_{3}, \mathrm{TiO}_{2}$, and HZSM-supported $\mathrm{Pd}-\mathrm{Cu}$ catalysts at the same $\mathrm{Pd}-\mathrm{Cu}$ loading.

\section{Experiment}

\subsection{Materials}

$\mathrm{Pd}\left(\mathrm{NO}_{3}\right)_{2} \cdot 2 \mathrm{H}_{2} \mathrm{O}$ (analytical grade) was purchased from Tianjin Wenda Sparseness \& Noble Reagent Chemical Factory. Molecular sieve (HZSM) was obtained from Nankai Catalyst Factory. $\mathrm{Al}_{2} \mathrm{O}_{3}, \mathrm{TiO}_{2}$, $\mathrm{Mg}\left(\mathrm{NO}_{3}\right)_{2} \cdot 6 \mathrm{H}_{2} \mathrm{O}, \mathrm{Al}\left(\mathrm{NO}_{3}\right)_{3} \cdot 9 \mathrm{H}_{2} \mathrm{O}$, and $\mathrm{Cu}\left(\mathrm{NO}_{3}\right)_{2} \cdot 3 \mathrm{H}_{2} \mathrm{O}$ (analytical grade) were purchased from Beijing Chemical Reagents Company.

\subsection{Preparation of hydrotalcite support}

Hydrotalcite was prepared by coprecipitation with low supersalturation method. In this method, two solutions, $\mathrm{A}$ and $\mathrm{B}$, were added dropwise into a beaker containing $100 \mathrm{~mL}$ of deionic water while vigorously stirring. Solution A was $\mathrm{Mg}\left(\mathrm{NO}_{3}\right)_{2}(1.2 \mathrm{~mol} / \mathrm{L})$ and $\mathrm{Al}\left(\mathrm{NO}_{3}\right)_{2}(0.4 \mathrm{~mol} / \mathrm{L})$ mixed aqueous solution. Solution B contained $1.65 \mathrm{~mol} / \mathrm{L} \mathrm{NaOH}$ and $0.5 \mathrm{~mol} / \mathrm{L} \mathrm{Na}_{2} \mathrm{CO}_{3}$. During the synthesis process, the $\mathrm{pH}$ of the suspension kept at about 10 . This process was completed within 30 min. Then the resulting suspension was continuously stirred for $4 \mathrm{~h}$. The product was filtered, washed thoroughly with deionised water until the $\mathrm{pH}$ of filtrate showed neutral and subsequently dried overnight at $105^{\circ} \mathrm{C}$, and calcined at $550^{\circ} \mathrm{C}$ for $8 \mathrm{~h}$. The final product was expressed as $\mathrm{HT}(\mathrm{Mg} / \mathrm{Al}=3$ ) (3 is the molar ratio of $\left.\mathrm{Mg}^{2+} / \mathrm{Al}^{3+}\right)$.

\subsection{Preparation of catalysts}

The catalysts were prepared by co-impregnation method. Different supports $\left(\mathrm{Al}_{2} \mathrm{O}_{3}, \mathrm{TiO}_{2}, \mathrm{HZSM}\right.$, $\mathrm{HT}(\mathrm{Mg} / \mathrm{Al}=3))$ of $3 \mathrm{~g}$ were put into the $\mathrm{Pd}\left(\mathrm{NO}_{3}\right)_{2} \cdot 2 \mathrm{H}_{2} \mathrm{O}$ and $\mathrm{Cu}\left(\mathrm{NO}_{3}\right)_{2} \cdot 3 \mathrm{H}_{2} \mathrm{O}$ mixed aqueous solution. The contents of $\mathrm{Pd}$ and $\mathrm{Sn}$ on the support were $1 \mathrm{wt} \%$ and 0.25 $\mathrm{wt} \%$, respectively. After stirring for $14 \mathrm{~h}$, the slurry was evaporated to dryness in a rotary evaporator at $80{ }^{\circ} \mathrm{C}$ under reduced pressure. The resulting paste was dried at $110{ }^{\circ} \mathrm{C}$ for $12 \mathrm{~h}$, and then calcined in air at $500{ }^{\circ} \mathrm{C}$ for $2 \mathrm{~h}$, and finally reduced at $500{ }^{\circ} \mathrm{C}$ for $1 \mathrm{~h}$ under flowing hydrogen/argon.

\subsection{Adsorptive and catalytic tests}

Catlytic capacities of the different catalysts for nitrate reduction were tested in an airtight stainless reactor with effective volume of $500 \mathrm{~mL}$. The catalyst $(1 \mathrm{~g})$ was suspended in pure water $(500 \mathrm{~mL})$, which was saturated with the mixture of argon $(400 \mathrm{~mL} / \mathrm{min})$ and hydrogen $(200 \mathrm{~mL} / \mathrm{min})$ from the titanium plate situated in the bottom of the reactor for $60 \mathrm{~min}$. The reaction started by adding a concentrated $\mathrm{NaNO}_{3}$ solution, where the initial nitrate concentration was $100 \mathrm{mg}$ $\mathrm{NO}_{3}^{-} \cdot \mathrm{L}^{-1}$. The temperature of the reaction was maintained at $25^{\circ} \mathrm{C}$. The pressure in the reactor was equal to the atmospheric pressure. $3 \mathrm{~mL}$ of solution was taken regularly from the reactor cell for analysis of $\mathrm{NO}_{3}^{-}, \mathrm{NO}_{2}^{-}$ and $\mathrm{NH}_{4}^{+}$.

For all adsorptive tests in this work, the experimental conditions were the same as those for the catalytic reduction of nitrate, but no hydrogen was provided.

\subsection{Definition of the activity and selectivity}

The activity for the reduction of nitrate is defined by the reduced amount of $\mathrm{NO}_{3}^{-}-\mathrm{N}$ per minute and per gram catalyst $\left(\mathrm{mg}-\mathrm{NO}_{3}^{-} \mathrm{N} \cdot \mathrm{min}^{-1} \cdot \mathrm{g}_{\mathrm{cat}}{ }^{-1}\right)$ after $3 \mathrm{~h}$ reaction.

The selectivity for the reduction of nitrate is defined by the ratio of the reduced amount of TN to the reduced amount of $\mathrm{NO}_{3}^{-}-\mathrm{N}$ after $3 \mathrm{~h}$ reaction.

The removal rate of nitrate $\left(X_{\mathrm{NO}_{3}}\right)$ is the ratio of the removed amount of nitrate to the initial amount of nitrate, that is, $X_{\mathrm{NO}_{3}^{-}}=\left(\left[\mathrm{NO}_{3}^{-}\right]_{t=0}-\left[\mathrm{NO}_{3}^{-}\right]_{t=t}\right) /\left[\mathrm{NO}_{3}\right]_{t=0}$.

\subsection{Analysis methods}

Samples were taken from the reactor at desired sampling time and filtered through a $0.45 \mu \mathrm{m}$ membrane. $\mathrm{NO}_{3}^{-}-\mathrm{N}, \mathrm{NO}_{2}^{-}-\mathrm{N}$ and $\mathrm{NH}_{4}^{+}-\mathrm{N}$ were determined using a Hitachi-3010 model UV-spectrophotometer. After the reaction, solution in the reactor was analyzed by ICP-OES (Perkin Elmer Co.) to quantify any dissolution of the metals (magnesium, aluminium, palladium and copper).

The actual quantity of active metals $(\mathrm{Pd}$ and $\mathrm{Cu})$ of the catalyst was analyzed as follows. First, the catalyst 
was dissolved in royal water $\left(\mathrm{HNO}_{3}: \mathrm{HCl}=1: 3\right)$. Then the solution was diluted to measure the quantity of $\mathrm{Pd}$ and $\mathrm{Cu}$ in solution by ICP-OES, which is the actual amount of active metals on the support.

The specific surface area (BET method), the volume and the average diameter of pores were determined using an ASAP2000 Surface Analyser (Micromeritics Co., USA) using $\mathrm{N}_{2}$ as the adsorbate. The size of the catalyst was observed on field transmission electron microscope (FTEM) (JEOL-2010 model). Acceleration voltage was $200 \mathrm{kV}$. The morphology of the catalyst was obtained on a scan electron microscope (SEM) (S-3000N model, HITACHI Co.). X-ray powder diffraction (XRD) patterns of samples were obtained with a Bruker diffractometer using $\mathrm{Cu} \mathrm{K} \alpha$ radiation from $5^{\circ}$ to $70^{\circ}$ (in $2 \theta$ ), and $\lambda$ is $0.15406 \mathrm{~nm}$. X-ray photoelectron spectrum (XPS) analysis was performed with an ESCALab220iXL electron spectrometer from VG Scientific using 300 $\mathrm{W} \mathrm{Mg} \mathrm{K} \alpha$ radiation.

\section{Results and discussion}

\subsection{Characterization of catalyst}

Generally, the capacities of the catalysts were obviously influenced by their characteristics such as the specific surface area, the volume and the average diameter of pores. In this study, the main characteristics of the Pd-Cu catalysts on different supports ( $\mathrm{HT}(\mathrm{Mg} / \mathrm{Al}$ =3), $\mathrm{Al}_{2} \mathrm{O}_{3}, \mathrm{TiO}_{2}$ and HZSM) are summarized in Table 1. The surface area of the $\mathrm{HT}(\mathrm{Mg} / \mathrm{Al}=3)$-supported Pd-Cu catalyst was $185.3 \mathrm{~m}^{2} / \mathrm{g}$, which was lower than that of $\mathrm{Al}_{2} \mathrm{O}_{3}$-supported catalyst $\left(284.7 \mathrm{~m}^{2} / \mathrm{g}\right)$ and HZSM-supported catalyst $\left(352.3 \mathrm{~m}^{2} / \mathrm{g}\right)$. $\mathrm{TiO}_{2}$-supported catalyst possessed a minimum $\left(12.4 \mathrm{~m}^{2} / \mathrm{g}\right)$ of the surface area. Accordingly, the surface area of the four catalysts decreased in the order: $\mathrm{HZSM}>\mathrm{Al}_{2} \mathrm{O}_{3}>\mathrm{HT}$ $(\mathrm{Mg} / \mathrm{Al}=3)>\mathrm{TiO}_{2}$. Additionally, it was noted that $\mathrm{HT}$ $(\mathrm{Mg} / \mathrm{Al}=3)$-supported $\mathrm{Pd}-\mathrm{Cu}$ catalyst exhibited mesopore structure with an average pore diameter of $52.3 \AA$. The maximum average pore diameter was observed on $\mathrm{Al}_{2} \mathrm{O}_{3}$-supported catalyst for $128.9 \AA$, the next is
$\mathrm{TiO}_{2}$-supported catalyst for $60.7 \AA$, and the lowest is HZSM-supported catalyst for $16.2 \AA$, that is, the average pore diameter of the catalysts was depressed as $\mathrm{Al}_{2} \mathrm{O}_{3}>\mathrm{TiO}_{2}>\mathrm{HT}(\mathrm{Mg} / \mathrm{Al}=3)>\mathrm{HZSM}$. Therefore, HT $(\mathrm{Mg} / \mathrm{Al}=3)$ prepared in our study is suitable for the support of the catalyst. Other supports, $\mathrm{TiO}_{2}$ with low surface area, HZSM with high surface area and micropore structure, $\mathrm{Al}_{2} \mathrm{O}_{3}$ with high surface area and mesopore structure material, are selected because they are representative.

The X-ray diffraction (XRD) analysis of the HT $(\mathrm{Mg} / \mathrm{Al}=3)$-supported $\mathrm{Pd}-\mathrm{Cu}$ catalyst showed that prior to the calcination, sharp and strong peaks at $12.1^{\circ}$, $23.58^{\circ}, 34.74^{\circ}$ appeared, indicating that the sample possessed layer structure. A well-crystallized hydrotalcite phase was identified according to the XRD pattern. After the calcination, the peaks corresponding to the hydrotalcite phase disappeared, i.e. layer structure was changed. $\mathrm{MgO}$ phase was formed according to the peaks at $43.2^{\circ}$ and $62.7^{\circ}$. This change was due to the calcination at high temperature which made the atoms on the surface of the catalyst arrange again. In addition, because of the low active metals content, no peak related with $\mathrm{Pd}-\mathrm{Cu}$ could be observed. When the sample was put into nitrate aqueous solution, the XRD pattern showed that hydrotalcite phase was regenerated ${ }^{[16]}$. Nitrate ions in water may be concentrated in the interlayer space of hydrotalcite, and then reduced. Accordingly, it can be speculated that hydrotalcite may be a favorable support for the catalytic reduction process.

$\mathrm{SEM} / \mathrm{FTEM}$ analysis of the $\mathrm{HT}(\mathrm{Mg} / \mathrm{Al}=3)$-supported $\mathrm{Pd}-\mathrm{Cu}$ catalyst after the calcination is shown in Fig. 1. The result showed that the active metal clusters were homogeneously dispersed on the support. Developed porous structure resulted in the high surface area. The size of most metal clusters was about $20 \mathrm{~nm}$, which favored the improvement of the catalytic activity of the catalyst.

The valence state of the active metals coated on the hydrotalcite was studied by XPS in Fig. 2. According to the calculation, the weight ratio of $\mathrm{Pd} / \mathrm{Cu}$ on the surface

Table 1 The characteristics of the catalysts on different supports

\begin{tabular}{cccccccc}
\hline $\mathrm{Pd}(\mathrm{wt} \%)$ & $\mathrm{Cu}(\mathrm{wt} \%)$ & Support & $\begin{array}{c}\text { Actual amount of } \mathrm{Pd} \\
(\mathrm{wt} \%)\end{array}$ & $\begin{array}{c}\text { Actual amount of } \mathrm{Cu} \\
(\mathrm{wt} \%)\end{array}$ & $\begin{array}{c}\mathrm{BET} \\
\left(\mathrm{m}^{2} / \mathrm{g}\right)\end{array}$ & $\begin{array}{c}\text { Volume of pores } \\
(\mathrm{mL} / \mathrm{g})\end{array}$ & $\begin{array}{c}\text { Average diameter of } \\
\text { pores }(\AA)\end{array}$ \\
\hline \multirow{3}{*}{1} & & $\mathrm{TiO}_{2}$ & 1.11 & 0.25 & 12.4 & 0.02 & 60.7 \\
& \multirow{2}{*}{0.25} & $\mathrm{HZSM}$ & 1.04 & 0.26 & 352.3 & 0.19 & 16.2 \\
& & $\mathrm{Al}_{2} \mathrm{O}_{3}$ & 1.01 & 0.23 & 284.7 & 0.91 & 128.9 \\
& & $\mathrm{HT}(\mathrm{Mg} / \mathrm{Al}=3)$ & 1.08 & 0.24 & 185.3 & 0.24 & 52.2 \\
\hline
\end{tabular}




\section{ARTICLES}
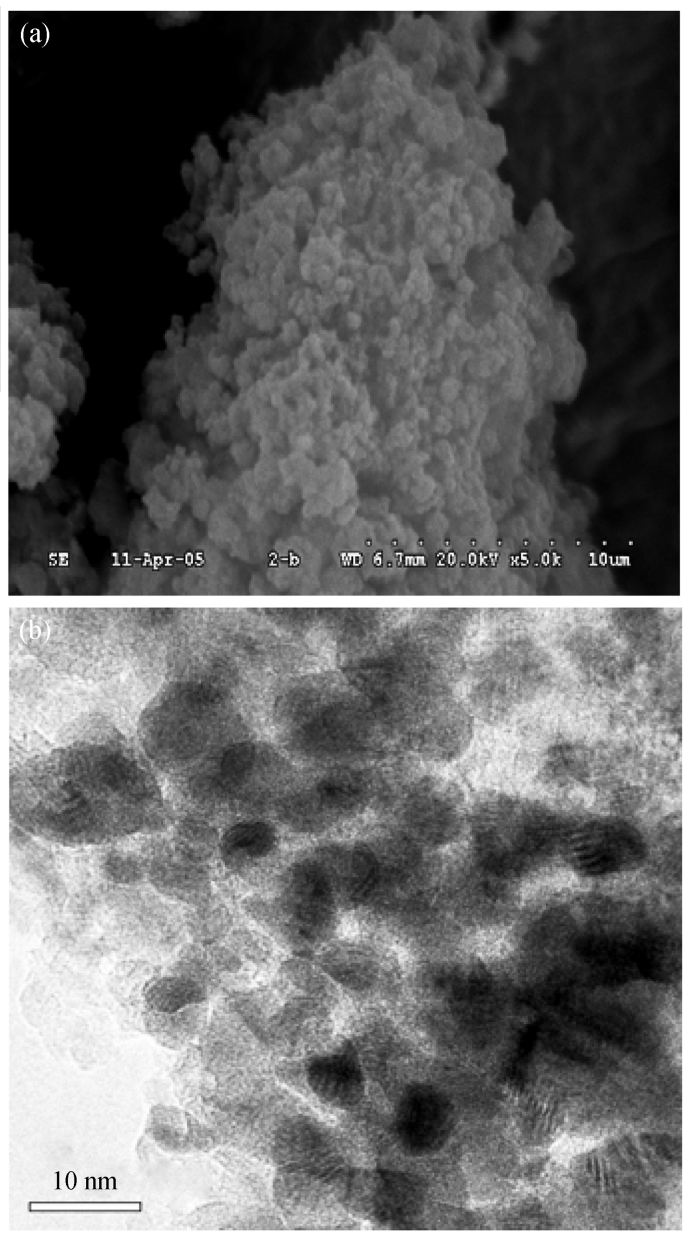

Fig. 1. SEM (a) and FTEM (b) of the $\mathrm{HT}(\mathrm{Mg} / \mathrm{Al}=3)$-supported $\mathrm{Pd}-\mathrm{Cu}$ catalyst.

of the catalyst was 3.3 (the molar ratio was 1.95 ). The analysis for the $\operatorname{Pd} 3 \mathrm{~d}_{5 / 2}$ spectrum suggested that two peaks at ca. 337.9 and $335.8 \mathrm{eV}$ were observed, which was characteristic of the oxide and metallic Pd, with the most being in metallic state. Two maximums at ca. 932.8 and $934.6 \mathrm{eV}\left(\mathrm{Cu} 2 \mathrm{p}_{3 / 2}\right)$ indicated that $\mathrm{Cu}$ on the surface of the catalyst presented $\mathrm{Cu}^{0}\left(\right.$ or $\left.\mathrm{Cu}^{+}\right)$and $\mathrm{Cu}^{2+}$, in which $\mathrm{Cu}^{0}$ (or $\mathrm{Cu}^{+}$) state was dominant. As a result, the active metals on the surface of the $\mathrm{HT}(\mathrm{Mg} / \mathrm{Al}=3)$ supported $\mathrm{Pd}-\mathrm{Cu}$ catalyst were mostly reduced.

\subsection{Adsorption capacity for nitrate}

Compared with the $\mathrm{Al}_{2} \mathrm{O}_{3}, \mathrm{TiO}_{2}$, and HZSM-supported catalysts, the adsorptive capacity for nitrate on the $\mathrm{HT}(\mathrm{Mg} / \mathrm{Al}=3)$-supported $\mathrm{Pd}-\mathrm{Cu}$ catalyst is shown in Fig. 3.

The process of adsorption for nitrate on the HT $(\mathrm{Mg} / \mathrm{Al}=3)$-supported $\mathrm{Pd}-\mathrm{Cu}$ catalyst may be divided into three stages. In the initial $2 \mathrm{~min}$, the concentration
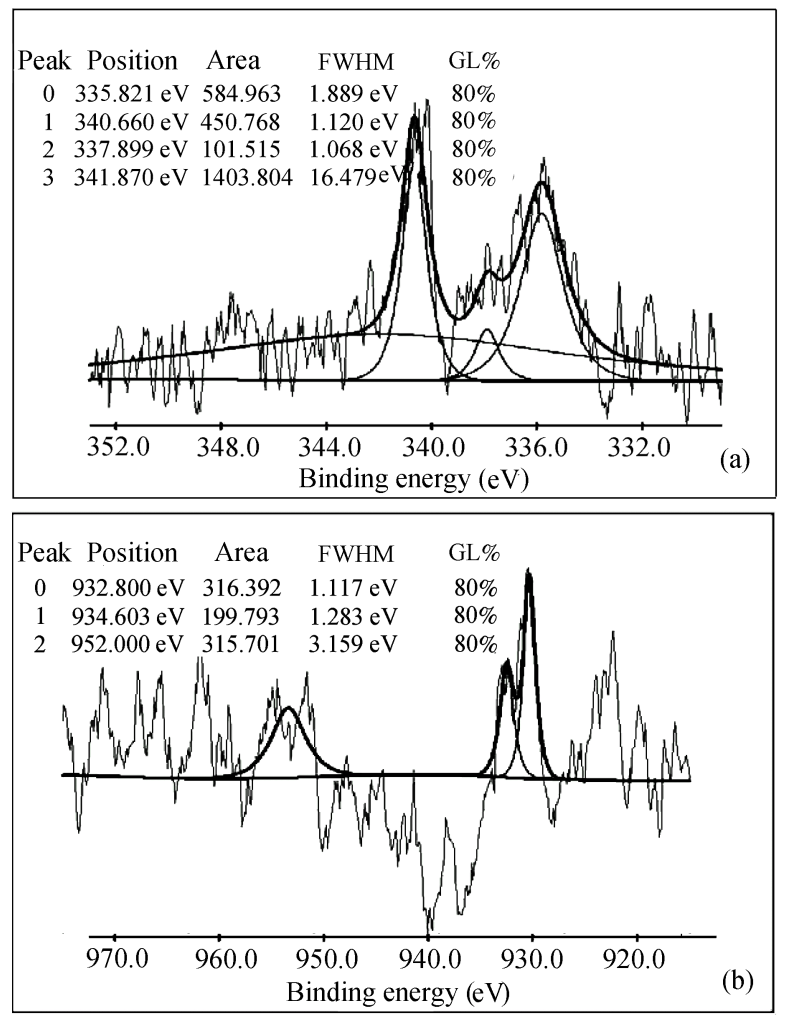

Fig. 2. XPS of the Pd $3 d$ (a) and $\mathrm{Cu} 2 \mathrm{p}$ (b) on the $\mathrm{HT}(\mathrm{Mg} / \mathrm{Al}=3)$-supported Pd-Cu catalyst.

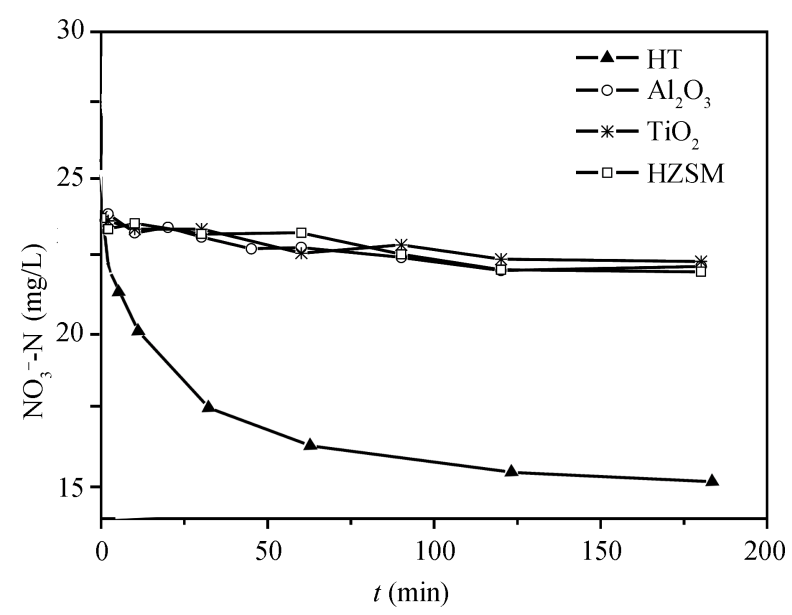

Fig. 3. The adsorption for nitrate on the catalysts with different supports at $25^{\circ} \mathrm{C}$.

of $\mathrm{NO}_{3}^{-}-\mathrm{N}$ decreased rapidly from 23.08 to $20.6 \mathrm{mg} / \mathrm{L}$, that is, $10.75 \%$ of nitrate ions was reduced. Then, nitrate removal rate became slow gradually. After $30 \mathrm{~min}$ reaction, $\mathrm{NO}_{3}^{-}-\mathrm{N}$ concentration was $17.05 \mathrm{mg} / \mathrm{L}$ and the removal rate achieved $26.13 \%$. From 30 to $180 \mathrm{~min}$, a slow change of the nitrate concentration was observed. 


\section{ARTICLES}

The final $\mathrm{NO}_{3}^{-} \mathrm{N}$ concentration and the total removal rate reaction got to $14.66 \mathrm{mg} / \mathrm{L}$ and $36.48 \%$, respectively. Conversely, there was no obvious decrease in nitrate concentration when using the $\mathrm{Al}_{2} \mathrm{O}_{3}, \mathrm{TiO}_{2}$ and HZSM-supported catalysts, indicating that those catalysts showed little adsorptive capacity for nitrate.

A simple kinetic analysis of adsorption was tested using pseudo-second-order equation,

$$
d q_{t} / d t=k_{2}\left(q_{e}-q_{t}\right)^{2},
$$

where $q_{e}$ and $q_{t}(\mathrm{mg} / \mathrm{g})$ were the amounts of $\mathrm{NO}_{3}^{-}-\mathrm{N}$ adsorbed on catalyst at equilibrium and at time $t$, respectively, and $k_{2}(\mathrm{~g} / \mathrm{mg} / \mathrm{min})$ was the rate constant of pseudo second-order adsorption. The initial sorption rate $v_{0}(\mathrm{mg} / \mathrm{g} / \mathrm{min})$ was defined:

$$
v_{0}=k_{2} q_{e}^{2} .
$$

Obviously, the process of nitrate adsorption on the $\mathrm{HT}(\mathrm{Mg} / \mathrm{Al}=3)$-supported $\mathrm{Pd}-\mathrm{Cu}$ catalyst was in good agreement with the pseudo-second-order model $\left(R^{2}>\right.$ $0.97)$. The rate constant $\left(k_{2}\right)$ and the initial sorption rate of $\mathrm{NO}_{3}^{-}\left(v_{0}\right)$ were 0.025 and $0.44 \mathrm{mg} \cdot \mathrm{g}^{-1} \cdot \mathrm{min}^{-1}$, respectively.

Adsorption capacity at different $\mathrm{NO}_{3}^{-}$concentrations can be illustrated by the adsorption isotherm (Fig. 4). The experimental data were tested using Langmuir model:

$$
q_{e}=q_{m} b c_{e} /\left(1+b c_{e}\right),
$$

where $q_{e}(\mathrm{mg} / \mathrm{g})$ was the amount of $\mathrm{NO}_{3}^{-}-\mathrm{N}$ adsorbed at equilibrium, $q_{m}(\mathrm{mg} / \mathrm{g})$ was the maximum sorption capacity corresponding to complete monolayer coverage, $c_{e}(\mathrm{mg} / \mathrm{L})$ was the equilibrium solute concentration, and $b$ was the equilibrium constant $(\mathrm{L} / \mathrm{mg})$. It was evident that Langmuir model was well fit for the experimental

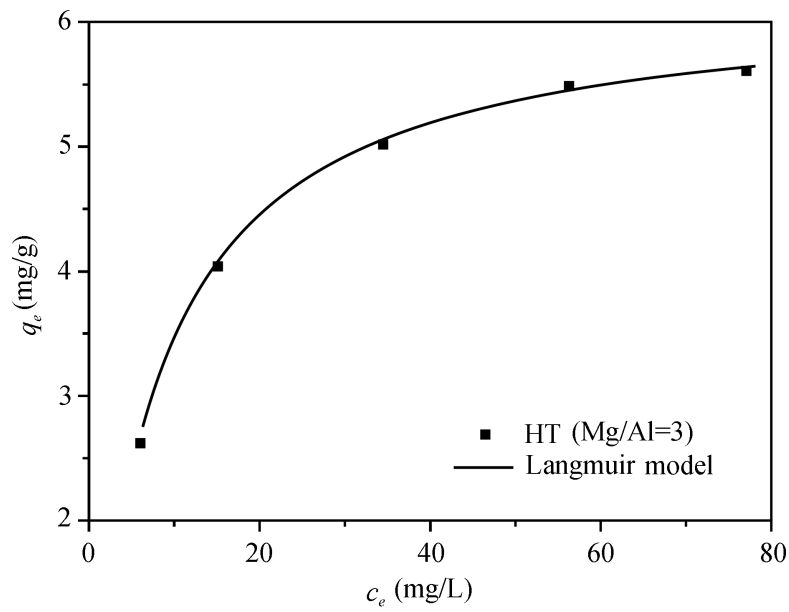

Fig. 4. The adsorption isotherm for nitrate on the $\mathrm{HT}(\mathrm{Mg} / \mathrm{Al}=3)$-supported Pd-Cu catalyst at $25^{\circ} \mathrm{C}$. data for the $\mathrm{HT}(\mathrm{Mg} / \mathrm{Al}=3)$-supported $\mathrm{Pd}-\mathrm{Cu}$ catalyst $\left(R^{2}>0.99\right)$. The maximum sorption capacity $\left(q_{m}\right)$ and the equilibrium constant $(b)$ were $6.22 \mathrm{mg} \cdot \mathrm{g}^{-1}$ and 0.126 $\mathrm{L} / \mathrm{mg}$, respectively.

Consequently, the $\mathrm{HT}(\mathrm{Mg} / \mathrm{Al}=3)$-supported $\mathrm{Pd}-\mathrm{Cu}$ catalyst possessed effective adsorption capacity for nitrate. This result may be related with the characteristics of hydrotalcite which, after calcination, reconstructed its layer structure when contacting water. During the regeneration of layer structure, nitrate ions were forced to enter the interlayer space to be concentrated. In the initial $30 \mathrm{~min}$, nitrate concentration decreased rapidly. Then, a slow change of nitrate concentration occurred due to the saturation of adsorption. Moreover, the adsorption kinetics and the adsorption isotherm of nitrate on the $\mathrm{HT}(\mathrm{Mg} / \mathrm{Al}=3)$-supported $\mathrm{Pd}-\mathrm{Cu}$ catalyst were fitted to the pseudo-second-order model and the Langmuir model, respectively. Thus it was speculated that the rate-limiting step was chemisorption, adsorption sites were homogeneous, and monolayer adsorption was dominant.

\subsection{Catalytic activity for nitrate reduction and the reaction scheme}

Compared with the $\mathrm{Al}_{2} \mathrm{O}_{3}, \mathrm{TiO}_{2}$, and HZSM-supported catalysts, the catalytic hydrogenation capacity for nitrate on the $\mathrm{HT}(\mathrm{Mg} / \mathrm{Al}=3)$-supported $\mathrm{Pd}-\mathrm{Cu}$ catalyst is shown in Fig. 5.

As shown in Fig. 5(a), in the initial 2 min, the concentration of $\mathrm{NO}_{3}^{-} \mathrm{N}$ decreased rapidly from 23.21 to $20.01 \mathrm{mg} / \mathrm{L}$, reaching $13.77 \%$ of removal rate. Then, the change became slow gradually. After 30 min reaction, $\mathrm{NO}_{3}^{-}-\mathrm{N}$ concentration was $16.63 \mathrm{mg} / \mathrm{L}$ and removal rate got to $28.34 \%$. After $180 \mathrm{~min}$, the final $\mathrm{NO}_{3}^{-}-\mathrm{N}$ concentration and the total removal rate reaction were $4.79 \mathrm{mg} / \mathrm{L}$ and $79.4 \%$, respectively. Comparably, within the initial $2 \mathrm{~min}, \mathrm{NO}_{3}^{-}-\mathrm{N}$ concentration decreased from 23.21 to $21.04 \mathrm{mg} / \mathrm{L}$ for $\mathrm{Al}_{2} \mathrm{O}_{3}$, to 21.04 $\mathrm{mg} / \mathrm{L}$ for $\mathrm{TiO}_{2}$, and to $21.51 \mathrm{mg} / \mathrm{L}$ for HZSM-supported catalyst, respectively. Corresponding nitrate removal rates were $41.3 \%, 25.1 \%$ and $25.1 \%$, respectively. Therefore, the initial and the average removal rates for nitrate on the $\mathrm{HT}(\mathrm{Mg} / \mathrm{Al}=3)$-supported $\mathrm{Pd}-\mathrm{Cu}$ catalyst were both higher than the $\mathrm{Al}_{2} \mathrm{O}_{3}, \mathrm{TiO}_{2}$, and HZSMsupported catalysts.

By analyzing the difference between the catalytic reduction and the adsorption for nitrate (Fig. 5(b)), a reaction scheme for the catalytic hydrogenation of nitrate on the hydrotalcite-supported $\mathrm{Pd}-\mathrm{Cu}$ catalyst was 


\section{ARTICLES}
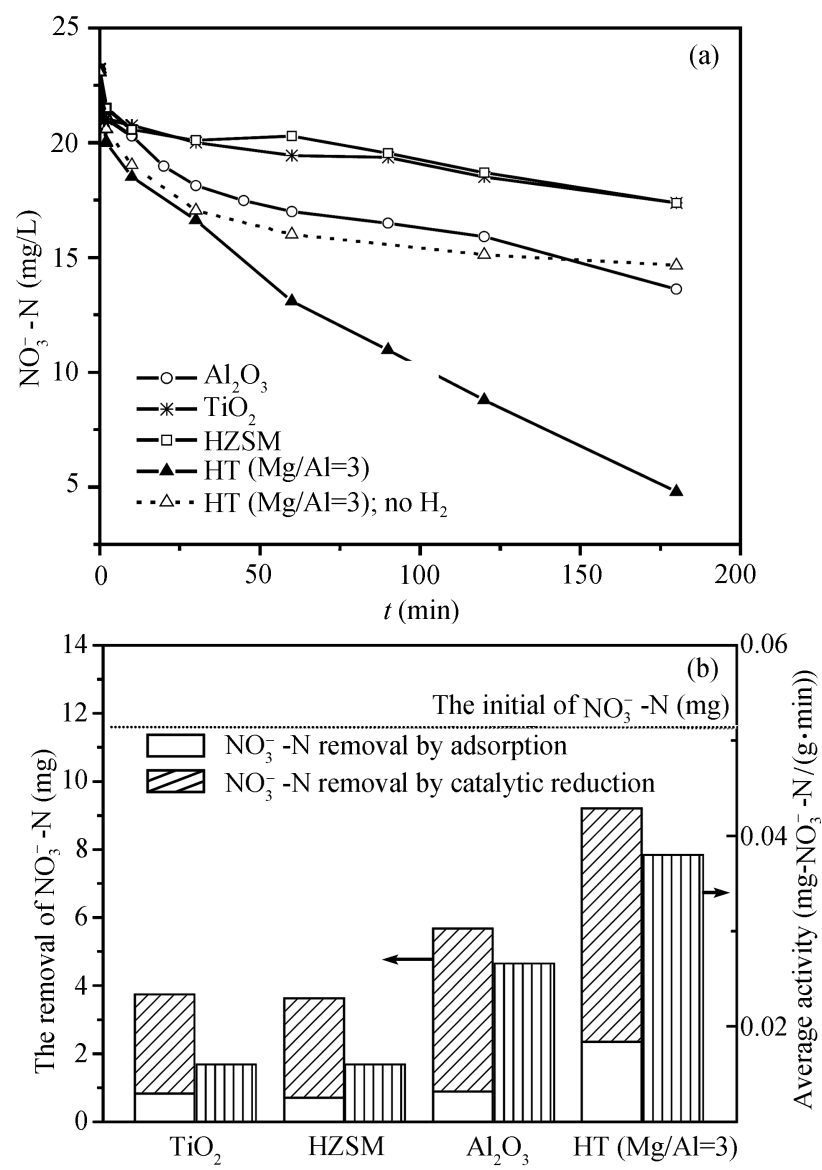

Fig. 5. The catalytic activity for nitrate on the catalysts with different supports. (a) The change of nitrate concentration with time; (b) the removal amount of nitrate by the adsorption and the reduction, and the average activity after 180 min reaction.

proposed. First, within the initial $30 \mathrm{~min}$, because of the regeneration of hydrotalcite structure, nitrate ions rapidly entered the interlayer space, i.e. the adsorption process dominated. Then, with the adsorption equilibrium achieved, the adsorption rate decreased gradually and became equal to the catalytic reduction rate. Subsequently, catalytic reduction rate increased to exceed the adsorption rate. Finally, when nitrate concentration in solution was very low, nitrate ions lying in the interlayer space continued to maintain catalytic hydrogenation. Therefore, the nitrate removal on the hydrotalcite-supported $\mathrm{Pd}-\mathrm{Cu}$ catalyst, with $\mathrm{H}_{2}$ provided, was a consecutive and dynamic adsorption and catalytic hydrogenation process.

In order to further clarify the adsorption and catalytic reduction process on the hydrotalcite-supported $\mathrm{Pd}-\mathrm{Cu}$ catalyst, the following experiment was conducted. After the reaction, the hydrotalcite-supported $\mathrm{Pd}-\mathrm{Cu}$ catalyst was taken out immediately, and then was dissolved in
$5 \mathrm{~mol} / \mathrm{L}$ hydrochloric acid. Then the dilution nitrate was measured. The experimental result revealed that the amount of $\mathrm{NO}_{3}^{-}-\mathrm{N}$ removed by the adsorption was $2.60 \mathrm{mg}$. When this value was subtracted from the total removal amount of $\mathrm{NO}_{3}^{-}-\mathrm{N}(9.21 \mathrm{mg})$, we obtained the amount of $\mathrm{NO}_{3}^{-}-\mathrm{N}$ removed by the catalytic reduction (6.61 $\mathrm{mg}$ ) on the hydrotalcite-supported $\mathrm{Pd}-\mathrm{Cu}$ catalyst, which was higher than that on the $\mathrm{Al}_{2} \mathrm{O}_{3}, \mathrm{TiO}_{2}$, and HZSM-supported catalysts (Fig. 5(b)). Additionally, the hydrotalcite-supported $\mathrm{Pd}-\mathrm{Cu}$ catalyst possessed the highest average catalytic activity for nitrate. Consequently, it was concluded that the hydrotalcite-supported $\mathrm{Pd}-\mathrm{Cu}$ catalyst showed higher average catalytic activity for nitrate than the $\mathrm{Al}_{2} \mathrm{O}_{3}, \mathrm{TiO}_{2}$, and HZSMsupported catalysts. Moreover, the amount of $\mathrm{NO}_{3}^{-}$removed by catalytic reduction was higher than that by the adsorption after 180 min reaction.

\subsection{Catalytic selectivity for nitrate reduction}

Simultaneously, nitrite and ammonium ions were formed during the catalytic hydrogenation for nitrate (Fig. 6(a) and (b)). Their concentrations rose with the increase of nitrate conversion. This result indicated that nitrate ions were reduced to the desired product nitrogen gas via intermediate product $\mathrm{NO}_{2}^{-}$, and at the same time ammonium ions as one of final products were produced. The accumulation of the $\mathrm{NO}_{2}^{-}$during the reaction demonstrated that the rate of nitrate reduction was higher than that of nitrite reduction.

The selectivity of the catalytic hydrogenation for nitrate was different on the catalysts with various supports (Fig. 6(c)). After $180 \mathrm{~min}$ reaction, the $\mathrm{NO}_{2}^{-}-\mathrm{N}$ and $\mathrm{NH}_{4}^{+} \mathrm{N}$ concentrations were 1.86 and $0.55 \mathrm{mg} / \mathrm{L}$ respectively, which were lower than the result reported by Palomares et al. ${ }^{[17]}$ who used the hydrotalcite-supported catalyst $(5 \mathrm{wt} \% \mathrm{Pd}-1.5 \mathrm{wt} \% \mathrm{Cu})$. Consequently, in our study, the catalytic reduction of nitrate on the hydrotalcite-supported $\mathrm{Pd}-\mathrm{Cu}$ catalyst exhibited higher selectivity, reaching $78.5 \%$. The highest selectivity was observed on the HZSM-supported catalyst (96.3\%). $\mathrm{TiO}_{2}$ and $\mathrm{Al}_{2} \mathrm{O}_{3}$-supported catalysts revealed lower selectivity for nitrate reduction, achieving $49.8 \%$ and $25.4 \%$ respectively. Accordingly, the selectivity of nitrate reduction on different catalysts had the following tendency: $\mathrm{HZSM}>\mathrm{HT}(\mathrm{Mg} / \mathrm{Al}=3)>\mathrm{TiO}_{2}>\mathrm{Al}_{2} \mathrm{O}_{3}$, which was contrary to the order of the average diameter of pores, that is, the larger the average diameter of pores on different catalysts, the lower the selectivity for nitrate reduction. 

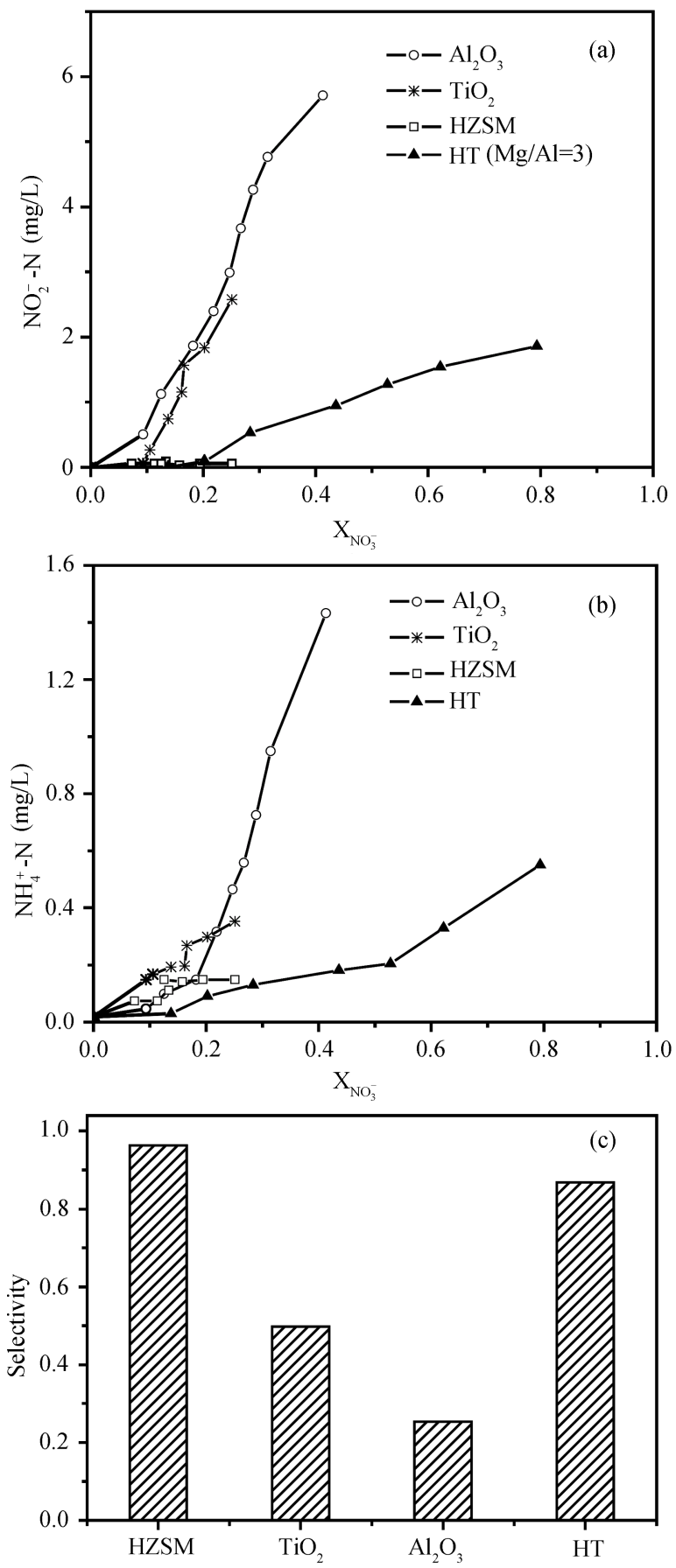

Fig. 6. The catalytic selectivity for nitrate on the catalysts with different supports. (a) The change of $\mathrm{NO}_{2}^{-}-\mathrm{N}$ concentration with $\mathrm{NO}_{3}^{-}$conversion; (b) the change of $\mathrm{NH}_{4}^{+}-\mathrm{N}$ concentration with $\mathrm{NO}_{3}^{-}$conversion; (c) the catalytic selectivity after $180 \mathrm{~min}$ reaction.

In conclusion, nitrate ions in water may be effectively removed by the catalytic hydrogenation process. However, the selectivity to $\mathrm{N}_{2}$ required to be further improved. Selecting a more suitable catalyst, optimizing the reaction conditions, combining with other tech- nologies, and reducing the formation of $\mathrm{NO}_{2}^{-}$and $\mathrm{NH}_{4}^{+}$ ions will be the main study fields in the future.

\subsection{Stability of the hydrotalcite-supported $\mathrm{Pd}-\mathrm{Cu}$ catalyst for nitrate reduction}

Generally, hydrolyzation exists on the surface of the hydrotalcite material, leading to the formation of magnesium hydroxide and aluminium hydroxide colloids. Thus it was necessary to evaluate the stability of the hydrotalcite-supported $\mathrm{Pd}-\mathrm{Cu}$ catalyst. After the reaction, the dissolution of metals in the solution was analyzed by ICP-OES. The concentrations of copper, magnesium and aluminium ions were $0.0034,1.55$ and $0.59 \mathrm{mg} / \mathrm{L}$, respectively. No palladium ions were detected in the solution. Therefore, little dissolution occurred on the surface of the hydrotalcite-supported $\mathrm{Pd}-\mathrm{Cu}$ catalyst. However, the concentrations of dissolved ions were all lower than the standard for drinking water.

To evaluate the stability of the hydrotalcite-supported $\mathrm{Pd}-\mathrm{Cu}$ catalyst during a long-term use, the experiment was conducted as follows. After the reaction, the catalyst was taken out by the centrifugation, and then washed to remove excess ions on the surface of the catalyst, whereafter, the recycled catalyst was dried at $60^{\circ} \mathrm{C}$ and weighed. Finally, the capacity of the recycled catalyst for nitrate reduction was examined again. The above experiment was repeated for five times. The result (Table 2) showed no apparent decline on the activity of nitrate reduction, indicating that the hydrotalcite-sup-ported $\mathrm{Pd}-\mathrm{Cu}$ catalyst exhibited excellent stability and may be used for a long term.

\begin{tabular}{ccccccc} 
Table 2 & \multicolumn{6}{c}{ The stability of the $\mathrm{HT}(\mathrm{Mg} / \mathrm{Al}=3)$-supported $\mathrm{Pd}-\mathrm{Cu}$ catalyst } \\
\hline Times & 1 & 2 & 3 & 4 & 5 \\
\hline $\begin{array}{c}\text { Recycle rate of } \\
\text { the catalyst }(\%)\end{array}$ & 100 & 93 & 89 & 83 & 74 \\
$\begin{array}{c}\text { Average activity } \\
\left(\mathrm{mg}-\mathrm{NO}_{3}^{-}-\mathrm{N} /(\mathrm{g} \text { min })\right)\end{array}$ & 0.037 & 0.034 & 0.033 & 0.033 & 0.032 \\
\hline
\end{tabular}

\section{Conclusions}

The hydrotalcite-supported $\mathrm{Pd}-\mathrm{Cu}$ catalyst prepared by co-impregnation method possessed high surface area and mesopore structure. The active metal clusters were homogeneously dispersed on the support, and the size of the most was lower than $10 \mathrm{~nm}$. Active metals of Pd and $\mathrm{Cu}$ on the surface of the catalyst presented oxide and metallic state, in which metallic state was dominant. The experimental results demonstrated that the hydrotalcite-supported $\mathrm{Pd}-\mathrm{Cu}$ catalyst exhibited excellent 
adsorptive and catalytic performances for nitrate in water.

The X-ray diffraction (XRD) analysis of the HT $(\mathrm{Mg} / \mathrm{Al}=3)$-supported $\mathrm{Pd}-\mathrm{Cu}$ catalyst indicated that layer structure recovered when the calcined sample was in the aqueous solution, which resulted in the fact that nitrate ions rapidly entered the interlayer space in the initial $2 \mathrm{~min}$. After $3 \mathrm{~h}$, the concentration of $\mathrm{NO}_{3}^{-}-\mathrm{N}$ decreased from 23.08 to $14.66 \mathrm{mg} / \mathrm{L}$. The removal rate and the amount of adsorption for nitrate were $26.13 \%$ and $4.21 \mathrm{mg} \mathrm{NO}-\mathrm{N} / \mathrm{g}$, respectively. Therefore, the $\mathrm{HT}(\mathrm{Mg} / \mathrm{Al}=3)$-supported $\mathrm{Pd}-\mathrm{Cu}$ catalyst possessed effective adsorption property for nitrate. Moreover, the adsorption kinetics and the adsorption isotherm of nitrate on the $\mathrm{HT}(\mathrm{Mg} / \mathrm{Al}=3)$-supported $\mathrm{Pd}-\mathrm{Cu}$ catalyst were fitted to the pseudo-second-order model and the Langmuir model, respectively, which demonstrated that the rate-limiting step was chemisorption and adsorption sites were homogeneous.

The catalytic reduction of nitrate with hydrogen on the hydrotalcite-supported $\mathrm{Pd}-\mathrm{Cu}$ catalyst was a consecutive and dynamic adsorption and catalytic hydrogenation process. After $3 \mathrm{~h}$ reaction, the concentration of $\mathrm{NO}_{3}^{-}-\mathrm{N}$ declined from 23.21 to $4.79 \mathrm{mg} / \mathrm{L}$, achieving $79.4 \%$ of removal. A small amount of $\mathrm{NO}_{2}^{-}$and $\mathrm{NH}_{4}^{+}$ ions was produced, i.e. higher selectivity to $\mathrm{N}_{2}$ was observed. Consequently, compared with the $\mathrm{Al}_{2} \mathrm{O}_{3}, \mathrm{TiO}_{2}$ and HZSM-supported $\mathrm{Pd}-\mathrm{Cu}$ catalysts, the HT $(\mathrm{Mg} / \mathrm{Al}=3)$-supported $\mathrm{Pd}-\mathrm{Cu}$ catalyst exhibited higher catalytic activity and selectivity. Additionally, hydrolyzation existed on the surface of the hydrotalcite-supported $\mathrm{Pd}-\mathrm{Cu}$ catalyst. However, the concentrations of dissolved metals in the solution were lower than the standard for drinking water. The activity of the hydrotalcite-supported $\mathrm{Pd}-\mathrm{Cu}$ catalyst for nitrate reduction kept steady after repeated use, which favored the longterm use.

To sum up, due to the characteristics of hydrotalcite which, after calcination, reconstructed its layer structure when contacting water, nitrate ions were forced to enter the interlayer space, and then reduced further. Accordingly, the $\mathrm{HT}(\mathrm{Mg} / \mathrm{Al}=3)$-supported $\mathrm{Pd}-\mathrm{Cu}$ catalyst showed higher catalytic activity and selectivity for nitrate.

Acknowledgements This work was supported by the National Science Fund for Distinguished Young Scholars (Grant No. 50225824).

\section{References}

1 Super M, Heese H de V, MacKenzie D, et al. An epidemiological study of well-water nitrates in a group of south west african/ na mibian infants. Water Res, 1981, 15(11): 1265-1270

2 Kapoor A, Viraraghavan T. Nitrate removal from drinking water. J Environ Eng, 1997, 4: 371-378

3 Flere O M, Zhang T C. Nitrate removal with sulfurlimestone autotrophic denitrification processes. J Environ Eng, 1999, 125(8): $721-729$

4 Prusse U, Vorlop K D. Supported bimetallic palladium catalysts for water-phase nitrate reduction. J Mol Catal A: Chem, 2001, 173: $313-328$

5 Vorlop K D, Tacke T. Este schritte auf dem weg zur edelmetall katalysierten nitr. und nitritentfernung aus trinkwasser. Chem Ing Tech, 1989, 61: 836-845

6 Hoerold S, Tacke T, Vorlop K D. Catalytic removal of nitrate and nitrite from drinking water-1. Screening for hydrogenation catalysts and influence of reaction conditions on activity and selectivity. Environ Techno, 1993, 14: 931-945

7 Pintar A, Marko S, Levec J. Hardness and salt effects on catalytic hydrogenation of aqueous nitrate solutions. J Catal, 1998, 174(1): $72-87$

8 Centi G, Perathoner S. Remediation of water contamination using catalytic technologies. Appl Catal B: Environmental, 2003, 41: $15-29$

9 Ilinitch O M, Geibov E N, Simonov P A. Water denitrification over catalytic membranes: Hydrogen spillover and catalytic activity of macroporous membranes loaded with $\mathrm{Pd}$ and $\mathrm{Cu}$. Catal Today, 2003, 82: 49-56

10 Gao W L, Guan N J, Chen J X, et al. Titania supported Pd-Cu bimetallic catalyst for the reduction of nitrate in drinking water. Appl Catal B: Environmental, 2003, 46(2): 341-351

11 Lemaignen L, Tong C, Begon V, et al. Catalytic denitrification of water with palladium-based catalysts supported on activated carbons. Catal Today, 2002, 75: 43-48

12 Berndt H, Monnich I, Lucke B, et al. Tin promoted palladium catalysts for nitrate removal from drinking water. Appl Catal B: Environmental, 2001, 30: 111-122

13 Strukul G, Gavagnin R, Pinna F, et al. Use of palladium based catalysts in the hydrogenation of nitrates in drinking water: From powders to membranes. Catal Today, 2000, 55: 139-149

14 Gavagnin R, Biasetto L, Pinna F. Nitrate removal in drinking waters: The effect of tin oxides in the catalytic hydrogenation of nitrate by $\mathrm{Pd} / \mathrm{SnO}_{2}$ catalysts. Appl Catal B: Environmental, 2002, 38: $91-99$

15 Fornasari G, Trifiro F, Vaccari A, et al. Novel low temperature $\mathrm{NO}_{x}$ storage-reduction catalysts for diesel light-duty engine emissions based on hydrotalcite compounds. Catal Today, 2002, 75: 421429

16 Wang Y, Qu J H, Wu R C, et al. Hydrotalcite-supported Pd-Cu catalyst for nitrate adsorption and reduction from water. The 2 nd Japan-China Workshop on Environ mental Catalysis and Eco-materials (ed. Kyushu University), Fukuoka, 2005, 94-95

17 Palomares A E, Prato J G, Márquez F, et al. Denitrification of natural water on supported $\mathrm{Pd} / \mathrm{Cu}$ catalysts. Applied Catalysis B: Environmental, 2003, 41: 3-13 